\title{
HUBUNGAN POLA ASUH TERHADAP STATUS GIZI BALITA DI WILAYAH KERJA PUSKESMAS DADOK TUNGGUL HITAM KOTA PADANG TAHUN 2018
}

\author{
Nurul Prihastita Rizyana1, Yulia $^{2}$

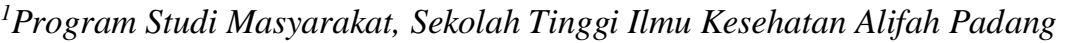 \\ Indonesia \\ Email :prihastitan@gmail.com \\ ${ }_{2}^{2}$ Program Studi Masyarakat, Sekolah Tinggi Ilmu Kesehatan Alifah Padang \\ Indonesia \\ yuliaskm88@gmailcom
}

\begin{abstract}
ABSTRAK
Sumatera barat merupakan salah satu dari 18 provinsi yang memiliki prevalensi diatas prevalensi nasional gizi buruk dan gizi kurang balita. Data menunjukkan bahwa persentase balita kurus dan sangat kurus berumur 0-59 bulan di Provinsi Sumatera Barat adalah berturut turut 1,9\% dan 7,0\%.Pola pengasuhan anak adalah penyebab tidak langsung yang memengaruhi status gizi balita,terutama pola asuh makan. Penelitian bertujuan mengetahui hubungan pola asuh dengan status gizi balita. Jenis penelitian studi observasional dengan desain cross sectional pada 60 sampel yang diambil secara accidental di Wilayah Kerja Puskesmas Dadok Tunggul Hitam kota Padang tahun 2018. Pengumpulan data dilakukan dengan wawancara langsung menggunakan kuesioner. Hasil penelitian menunjukkan 43,3\% balita dengan status gizi tidak baik, 53,3\% memiliki pola asuh yang tidak baik, uji chi-Square menunjukkan adanya hubungan bermakna antara pola asuh dengan status gizi balita $(\mathrm{p}<0,05)$.
\end{abstract}

Key word: Pola asuh, status gizi, malnutrisi

\begin{abstract}
West Sumatera is one of 18 provinces that has higher prevalence on malnutrition and chronic malnutrition than national prevalence average. Data shows that percentage of skinny children and very skinny children aged 0-59 months in West Sumatera are 1,9\% and 7\%, respectively. Parenting is the indirect factor that affects children nutritional status, especially eating pattern. Purpose of this research is to discover relations between parenting and and children nutritional status. Method of this research is observational study with cross-sectional design, involving 60 sample by accidental picks in working area of Puskesmas Dadok Tunggul Hitam, Padang, 2018. Data collection is conducted through interview with questionnaire. This research shows 43,3\% children with malnutrition, 53,3\% children with poor parenting, and chi-Square test shows significant relation between parenting and children nutritional status $(p<0,05)$.
\end{abstract}

Key word: Parenting, Children Nutritional Status, malnutrition 


\section{PENDAHULUAN}

Gizi memegang peranan penting dalam siklus hidup manusia sejak dalam kandungan sampai dengan lanjut usia. Undang-undang kesehatan tahun 2009 menyebutkan prioritas utama upaya perbaikan gizi di Indonesia adalah kelompok rawan yang salah satunya adalah bayi dan balita. Kekurangan gizi pada bayi dan balita dapat menimbulkan gangguan pertumbuhan dan perkembangan yang berlanjut hingga dewasa apabila tidak diatasi secara dini (Kemenkes, 2010).

Saat ini Indonesia termasuk salah satu dari 117 negara yang mempunyai tiga masalah gizi tinggi pada balita yaitu stunting, wasting dan overweight yang dilaporkan di dalam Global Nutrition Report (GNR) 2014 Nutrition Country Profile Indonesia. Prevalensi ketiga masalah gizi tersebut yaitu stunting 37,2\%, wasting $12,1 \%$ dan overweight 11,9\%. (IFPRI, 2014). Berdasarkan hasil Riset Kesehatan Dasar Tahun 2013 prevalensi nasional gizi buruk balita 5,7\% dan gizi kurang balita 13,9\%. Dari 33 provinsi terdapat 18 provinsi yang memiliki prevalensi diatas prevalensi nasional gizi buruk dan gizi kurang balita, salah satunya adalah Sumatera Barat.Status gizi masyarakat dipengaruhi oleh ketersediaan pangan keluarga, harga pangan, tingkat pendidikan, kesempatan kerja, pendapatan keluarga, daya beli keluarga, ketersediaan pangan, pola asuh/ perawatan anggota keluarga, kebersihan lingkungan/ kesehatan perorangan, dan akses ke pelayanan kesehatan (Carol Bellamy, 1999) dalam Edi, dkk (2015).

Pola asuh merupakan perilaku ibu atau pengasuh lain yang berhubungan dengan keadaan fisik dan mentalnya dalam memberikan kasih sayang dan perhatian, memberi makan dan kebersihan, mendidik perilaku dan lainnya. Pola asuh ibu memiliki pengaruh yang besar pada tumbuh kembang balita yang dapat meningkatkan status gizi balita. Seorang ibu harus mengetahui dan memahami cara mengasuh baik dalam bentuk perawatan maupun perlindungan yang mampu menciptakan keadaan yang nyaman bagi balita dalam mengkonsumsi makananya. Dalam meningkatkan status gizi balita diperlukan pola asuh yang baik dari ibu untuk meningkatkan nafsu makan baik dengan pengaturan menu makanan sehat, variasi makanan maupun cara pemberian makanan pada balita. (Sukirman, 2000).

Peranan wanita dalam keluarga tidak bisa dipisahkan dengan peran dan kedudukan mereka dalam keluarga. Wanita yang bekerja memiliki alasan bahwa bekerja merupakan suatu pilihan atau kebutuhan. Salah satunya adalah dikarenakan tingkat kemiskinan dan pengangguran yang semakin meningkat, sehingga ibu harus berkontribusi membantu perekonomian keluarga untuk memenuhi kebutuhan. Meningkatnya jumlah wanita yang memasuki dunia kerja di sektor publik merupakan fenomena yang perlu dicermati, khususnya berkaitan dengan berkembangnya peran yang harus dilakukan dan konsekuensi yang harus dihadapi dalam menjalankan perannya sebagai pengasuh utama bagi anak (Omar dan Astrid, 2015). Masuknya seorang ibu yang bekerja di dunia publik, setidaknya akan berpengaruh terhadap perannya di dalam rumah tangga, baik sebagai istri dengan perannya secara normatif yang berlaku di dalam masyarakat pada umumnya maupun sebagai seorang ibu yang mempunyai kewajiban memenuhi hak-hak dan kebutuhan dari anak-anaknya (Oemar dan Astrid, 2015).

Menurut Triaryati (2003) peran ibu modern yang sebagai pekerja maupun ibu rumah tangga mengakibatkan tuntutan yang lebih dari biasanya terhadap ibu. Penyeimbangan tanggung jawab ini cenderung lebih memberikan tekanan hidup bagi ibu bekerja karena selain menghabiskan banyak waktu dan energi, tanggung jawab ini memiliki tingkat kesulitan pengelolaan yang tinggi.

Dalam target SDGS 2030 tentang gizi masyarakat diharapkan dapat mengakhiri segala bentuk malnutrisi, termasuk mencapai target internasional 2025 untuk penurunan stunting dan wasting pada balita (Dirjen Gizi, 2015).

Data menunjukkan bahwa persentase balita kurus dan sangat kurus berumur 0-59 bulan di Provinsi Sumatera Barat adalah berturut turut 1,9\% dan $7,0 \%$, hasil ini lebih rendah jika dibandingkan dengan angka nasional dalam yaitu persentase balita kurus 3,1\% dan balita sangat kurus $8,0 \%$. ). Namun jika dibandingkan degan target nasional 
Volume 2 Nomor 2 P-ISSN : 2597-8594

tahun 2019 adalah 17\% maka prevalensi kekurangan gizi pada balita harus diturunk an 2,9\% dalam periode tahun 2013 (19.9\%) sampai tahun 2019 (17\%) (Sardjoko, 2016).

\section{METODE PENELITIAN}

Jenis penelitian yang telah dilakukan untuk melihat hubungan pola asuh ibu dengan status gizi ini adalah analitik kuantitatif dengan desain penelitian cross sectional. Dengan desain penelitian ini dapat diketahui hubungan pola asuh ibu dengan status gizi balita.Populasi penelitian ini adalah seluruh ibu yang memiliki balita di Kota Padang. Sampel penelitian ini diambil secara purposive sampling di Wilayah Kerja Puskemas Dadok Tunggul Hitam dengan pertimbangan banyaknya ibu yang memliki balita di Wilayah Kerja Puskesmas tersebut. Besar sampel penelitian ini adalah 60 orang ibu yang memiliki balita di Wilayah Kerja Puskesmas Dadok Tunggul Hitam.Penelitian ini dilakukan mulai dari BulanFebruari sampai dengan Mei 2018 di Kota Padang dimana tempat pengumpulan data adalah di Wilayah Kerja Puskesmas Dadok Tunggul Hitam pada bulan April 2018.

Data dikumpulkan menggunakan metode wawancara melalui kuesioner.Data penelitian ini diolah dengan menggunakan analisis univariat dan bivariate untuk melihat ada tidaknya hubungan pola asuh dengan ibu bekerja dengan status balita. Analisis univariat untuk gambaran proporsi karakteristik (tingkat pendidikan, jenis pekerjaan, usia) ibu bekerja, pola asuh dan status gizi. Sedangkan analisis bivariat untuk melihat hubungan pola asuh ibu dengan status gizi balita dengan menggunakan uji chi square dengan tingkat kepercayaan $95 \%$

\section{HASIL PENELITIAN}

Tabel 1

Distribusi Responden

Berdasarkan umur, pendidikan dan pekerjaan di kota padang tahun 2018

\begin{tabular}{|c|c|c|}
\hline $\begin{array}{l}\text { Karakteristik } \\
\text { Responden }\end{array}$ & Frekuensi & Proporsi \\
\hline a. $\quad$ Umur Ibu & & \\
\hline$<25$ Tahun & 14 & 23,3 \\
\hline$\geq 25$ Tahun & 46 & 76,7 \\
\hline b. Pendidikan & & \\
\hline SMP & 10 & 16,7 \\
\hline SMA & 17 & 28,3 \\
\hline $\mathrm{D} 3 / \mathrm{S} 1 / \mathrm{S} 2$ & 33 & 55,0 \\
\hline c. Pekerjaan & & \\
\hline Bekerja & 34 & 56,7 \\
\hline Tidak & 26 & 43,3 \\
\hline Bekerja & & \\
\hline Jumlah & 60 & 100.0 \\
\hline
\end{tabular}

Berdasarkan tabel 1 diatas dapat dilihat bahwa dari 60 responden terdapat 46 orang $(76,7 \%)$ ibu yang memiliki umur $\geq 25$ Tahun, 33 orang $(55,0 \%) \mathrm{ibu}$ yang berpendidikan D3/S1/S2, dan 34 orang $(56,7 \%)$ yang bekerja.

Tabel 2

Distribusi Proporsi Responden

BerdasarkanPola Asuh Pada Balita di Kota Padang Tahun 2018

\begin{tabular}{cll}
\hline Pola Asuh & Frekuensi & Proporsi \\
\hline Baik & 28 & 46,7 \\
Tidak & 32 & 53,3 \\
Baik & & \\
\hline Jumlah & 60 & 100
\end{tabular}

Berdasarkan tabel 2 diatas terdapat 32 orang $(53,3 \%) \mathrm{ibu}$ memiliki pola asuh pada balita yang tidak baik

Tabel 3

Distribusi Proporsi Responden

Berdasarkan Status Gizi Balita di Kota Padang Tahun 2018

\begin{tabular}{|c|c|c|}
\hline \multicolumn{3}{|l|}{$\begin{array}{ll}\text { Status } & \text { Gizi } \\
\text { Balita } & \end{array}$} \\
\hline Baik & 34 & 56,7 \\
\hline Tidak & 26 & 43,3 \\
\hline Baik & & \\
\hline Jumlah & 60 & 100 \\
\hline
\end{tabular}

Berdasarkan tabel 3 diatas terdapat 34 orang $(56,7 \%)$ balita yang memiliki status gizi yang baik 


\section{a. Hubungan Pola Asuh dengan Status Gizi Balita}

Hubungan Pola Asuh Responden Dengan Status Gizi Balita

di Kota Padang Tahun 2018

\begin{tabular}{llllllll}
\hline \multirow{2}{*}{$\begin{array}{l}\text { Pola } \\
\text { Asuh }\end{array}$} & \multicolumn{3}{l}{ Status Gizi Balita } & & \multicolumn{2}{l}{ Baik } & \multicolumn{3}{l}{$\begin{array}{l}\text { Tidak } \\
\text { Baik }\end{array}$} & Total & $\begin{array}{l}\boldsymbol{P} \\
\text { valu } \\
\boldsymbol{e}\end{array}$ \\
\cline { 2 - 7 } & $\mathbf{f}$ & $\mathbf{\%}$ & $\mathbf{f}$ & $\mathbf{\%}$ & $\mathbf{f}$ & $\mathbf{\%}$ & \\
\hline Baik & 2 & 89, & 3 & 10, & 2 & 100, & \\
& 5 & 3 & & 7 & 8 & 0 & \\
Tidak & 9 & 28, & 2 & 71, & 3 & 100, & 0,00 \\
Baik & & 1 & 3 & 9 & 2 & 0 & 0 \\
\hline Jumla & $\mathbf{3}$ & $\mathbf{5 6 ,}$ & $\mathbf{2}$ & $\mathbf{4 4 ,}$ & $\mathbf{6}$ & $\mathbf{1 0 0 ,}$ & \\
h & $\mathbf{4}$ & $\mathbf{7}$ & $\mathbf{6}$ & $\mathbf{3}$ & $\mathbf{0}$ & $\mathbf{0}$ & \\
\hline
\end{tabular}

Berdasarkan tabel 4 diatas dapat dilihat bahwa dari 60 responden terdapat proporsi ibu dengan pola asuh yang baik memiliki balita dengan status gizi baik sebanyak 89,3\% dan proporsi ibu dengan pola asuh tidak baik yang memiliki balita dengan status gizi tidak baik sebanyak $71,9 \%$.Hasil uji statistik chi square didapatkan nilai $\mathrm{p}$ value $0,000 \quad(\mathrm{p}<0,05)$ artinya terdapat hubungan yang bermakna antara pola asuh ibu yang menjadi responden dengan status gizi balita.

\section{PEMBAHASAN}

\section{a. Status gizi}

Hasil penelitian dengan menggunakan penilaian balita berdasarkan berat badan dibandingkan dengan umur $(\mathrm{BB} / \mathrm{U})$ menunjukkan dari 60 responden terdapat 34 responden yang berstatus gizi baik $(56,7 \%)$, dan 26 responden dengan status gizi tidak baik $(43,3 \%)$.Hasil penelitian ini sejalan dengan penelitian yang dilakukan Lubis (2008) dimana dijumpai lebih banya responden dengan status gizi baik $(77 \%)$. Menurut lubis (2008) hal ini dikarenakan karena ibu selalu memperhatikan keadaan gizi dan kesehatan anaknya. Hal ini sejalan dengan Putri (2015) salah satu faktor yang mempengaruhi status gizi adalah intake makanan.

Selain itu faktor eksternal menyangkut keterbatasan ekonomi keluarga dan pola asuh ibu. Sedangkan faktor internal yang terdapat pada diri anak yang secara psikologis muncul sebagai problem pada anak. Faktor yang berhubungan dengan status gizi anak salah satunya adalah faktor kondisi sosial ekonomi, antara lain pendidikan ibu, pekerjaan ibu, jumlah anak, pengetahuan dan pola asuh ibu serta kondisi ekonomi orang tua secara keseluruhan.

Lubis (2008) lebih Lanjut menjelaskan bahwa anak yang mempunyai status gizi baik (gemuk) dan kurus diasumsikan karena ini yang tidak memperhatikan asupan gizi anak serta kesehatan anak dan dapat juga disebabkan adanya penyakit infeksi yang semakin menambah buruk kondisi kesehatan anak sehinga pertumbuhan anak terganggu.

Hal ini sejalan dengan teori penyebab malnutrisi adalah multisektoral, meliputi makanan, infeksi penyakit yang disebut dengan penyebab langsung (tingkat individual) dan faktor tidak langsung (tumah tangga atau tingkat keluarga) seperti kerawanan pangan atau ketidakcukupan pangan, pola asuh anak yang tidak memadai, sanitasi air bersih, dimana faktor pada satu tingkat ada pengaruhnya ke tingkat lain (UNICEF, 1997) dalam Nur (2011).

Lubis (2008) menyebutkan bahwa prevalensi gizi kurang dan gizi buruk mulai meningkat pada usia 6-11 bulan dan mencapai puncaknya pada usia 12-23 bulan dan 24-35 bulan.

Hal ini sejalan dengan Fauziah (2009) dimana menyebutkan bahwa anak balita usia 1-3 tahun bersifat konsumen pasif, artinya makanan yang dikonsumsi tergantung pada apa yang disediakan oleh ibu, sehingga keterampilan ibu dalam rencana pemberian makanan juga perlu diperhatikan. Salah satu kemungkinan faktor yang menjelaskan bahwa status gizi baik lebih tinggi sebesar 53,3\% adalah faktor pendidikan dan umur ibu.

Makabutera (2016) menyebutkan bahwa ibu dengan usia matang cenderung memiliki anak dengan berat badan ideal karena berkaitan dengan keterampilan ibu dalam rencana pemberian makanan sehingga didapatkan status gizi anak yang baik. hal ini 
sejalan dengan hasil penelitian dimana didapatkan sebagian besar pendidikan ibu (55\%) adalah D3/S1/S2.

Kemungkinan lainnya adalah disebabkan karena pola asuh orang tua, pola asuh merupakan salah satu penyebab tidak langsung yang mungkin mempengaruhi pola makan terhadap balita. Hal ini sejalan dengan Debora (2013) dimana, pola asuh anak adalah perilaku yang dipraktikkan oleh pengasuh (ibu, bapak, nenek atau orang lain) dalam memerikan makanan, pemeliharaan kesehatan, memberikan stimuli serta dukungan emosional yang dibutuhkan anak untuk tumbuh-kembang anak, termasuk didalamnya kasih sayang dan tanggung jawab.

Rendahnya pola asuh akan menyebabkan rendahnya keadaan gizi balita, jika kondisi buruk terjadi pada masa golden period, otak tidak dapat berkembang dan kondisi ini sulit untuk dapat pulih kembali (Deborah, 2013). Hal ini didukung hasil penelitian bahwa terdapat $53,3 \%$ dengan pola asuh tidak baik.

\section{b. Pola asuh}

Lubis, (2008) menjelaskan bahwa pola asuh adalah kemampuan keluarga dan masyarakat untuk menyediakan waktu, perhatian dan dukungan dalam memenuhi kebutuhan fisik, mental dan sosial dari anak yang sedang tumbuh dan anggota keluarga lainnya. Pola asuh responden meliputi perhatian dan dukungan ibu terhadap dalam pemberian makanan, rangsangan psikososial dan praktek-praktek kesehatan.

Perhatian dan dukungan ibu dalam praktek pemberian makan juga termasuk ke dalam pola asuh dimana dapat diasumsikan pada ibu yang bekerja, dimana mempunyai waktu yang minim untuk anak dalam pemberian makan. Hal ini didukung oleh hasil penelitian dimana ibu yang bekerja lebih banyak $(56,7 \%)$ dibandingkan yang tidak bekerja sebesar 43,3\%.

Selain itu anak masih harus dibimbing saat makan, hal ini sesui dengan yang dikemukakan Nadesul (1995) bahwa anak masih membutuhkan bimbingan seorang ibu dalam memilih makanan agar pertumbuhan tidak terganggu. Bentuk perhatian dan dukungan ibu terhadap anak meliputi perhatian ketika anak makan dan sikap orang tua dalam memberi makan.yang penting untuk perkembangan kepribadian anak kelak kemudian hari.

Hal ini sejalan dengan penelitian Deborah (2013) dimana faktor yang paling dominan yang mempengaruhi kejadian stunting pada anak balita adalah riwayat pola asuh. Hal ini disebabkan tingginya jumlah ibu yang tidak memberikan ASI ekslusif kepada anaknya dan pemberian makanan pendamping ASI atau MP-ASI yang masih terlalu dini. Selain itu pola asuh juga dipengaruhi oleh pendidikan ibu dipengaruhi oleh faktor pendidikan ibu, lingkungan, serta budaya. Menurut Rikesdas (2013) semakin tinggi pendidikan orang semakin rendah prevalansi gizi buruk pada balita.

\section{c. Hubungan Pola Asuh dengan Status Gizi Balita}

Hasil penelitian membuktikan ada hubungan yang bermakna antara pola asuh dengan status gizi balita. Hasil penelitian ini sejalan dengan penelitian yang dilakukan Louriner,dkk (2014) dimana ditemukan hubungan yang bermakna antara pola asuh dengan status gizi balita di Puskesmas RanotamaWeru Manado.

Secara langsung status gizi dipengaruhi oleh asupan gizi dan penyakit infeksi yang mungkin diderita anak. Kedua penyebab langsung ini sangat terkait dengan pola asuh anak diberikan oleh ibu/pengasuh. Dan penyebab tidak langsung adalah ketahanan pangan di keluarga, pola pengasuhan anak serta pelayanan kesehatan dan kesehatan lingkungan. Ketiga faktor ini saling berkaitan dengan pendidikan, pengetahuan dan ketrampilan keluarga (Dinkes Sumatera Utara, 2006).

Hasil penelitian menunjukkan status gizi balita yang tidak baik lebih banyak dengan pola asuh yang tidak baik, hal ini menjelaskan bahwa responden yang masuk katagori ini adalah 23 orang, hal ini kemungkinan dikarenakan pengaruh faktor 
pendidikan ibu yang rendah, selain itu dikarenakan faktor lingkungan serta budaya. Menurut Riseksdas (2013) semakin tinggi tingkat pendidikan seseorang, semakin rendah prevalensi gizi buruk pada balita.

Menurut Mustapa, Sirajudin, Salam (2013) salah satu faktor yang berperan penting dalam status gizi balita adalah pola asuh, masalah gizi dipengaruhi oeleh banyak faktor yang kompleks ibu, keadaan gizi di pengaruhi oleh kemampuan ibu menyediakan pangan yang cukup untuk anak serta pola asuh yang dipengaruhi oleh faktor pendapatan keluarga, pendidikan, perilaku dan jumlah saudara.

Menurut Engle (1997), pola asuh adalah kemampuan keluarga dan masyarakat untuk menyediakan waktu, perhatian dan dukungan dalam memenuhi kebutuhan fisik, mental dan sosial dari anak yang sedang tumbuh dan anggota keluarga lainnya. Pola asuh responden meliputi perhatian/dukungan ibu terhadap anak dalam pemberian makanan, rangsangan psikososial dan praktek kesehatan anak.

Hasil penelitian (Fatimah, 2010) terdapat hubungan antara pola asuh dengan perkembangan anak, karena pola asuh orangtua merupakan gambaran tentang sikap dan perilaku orangtua dan anak dalam berinteraksi, berkomunikasi selama mengadakan kegiatan pengasuhan. Dalam kegiatan memberikan pengasuhan ini, orangtua akan memberikan perhatian, peraturan, disiplin, hadiah dan hukuman, serta tanggapan terhadap keinginan anaknya.

Perhatian/dukungan ibu terhadap anak dalam pemberian makan sangat penting karena ibu yang menyiapakan makanan dan mendampingi ketika anak makan. Bila anak tidak mau makan, ibu bisa membujuk anak agar mau menghabiskan makanannya. Ini sangat berhubungan dengan ketersediaan waktu ibu untuk memberi anaknya makan, apabila ibu bekerja maka waktu ibu untuk memberikan perhatian/dukungan ibu terhadap anak tentu akan berkurang.

Hal ini sesuai dengan Lubis (2008) dimana pola asuh ibu dalam memberikan perhatian/dukungan terhadap anak dalam pemberian makanan adalah dalam kategori baik, hal ini dikarenakan ibu selalu mendampingi anak makan karena sebagian besar ibu adalah Ibu Rumah Tangga (IRT) sebesat $81 \%$.

Didukung oleh penelitian yang dilakukan Sarasani (2005) bahwa anak yang mempunyai praktek pemberian makan yang baik lebih banyak yang berstatus gizi baik pula. Selain itu didukung oleh pendapat yang dikemukakan Engle dan Riccuti (1995) bahwa rangsangan psikosial yang baik umumnya berkaitan erat dengan status gizi dan kesehatan yang baik pula, sehingga secara tidak langsung berpengaruh positif terhadap status gizi, pertumbuhan dan perkembangan.

Hasil penelitian menemukan bahwa terdapat status gizi balita yang tidak baik namun memiliki pola asuh yang baik sebesar $10,7 \%$, hal itu terjadi karena anak yang susah untuk diatur, anak yang memang memiliki kebiasaan sulit makan dan hanya memilih makanan tertentu yang disukai, ada pula responden orang tua memiliki pola asuh yang tidak baik tetapi status gizi anak baik, hal ini terjadi karena orang tua yang sibuk bekerja menitipkan anak mereka ke rumah orang tua atau yang memiliki asisten rumah tangga sehingga kegiatan pengasuhan anak diganti oleh mereka dan anak pun menjadi terkontrol pola asuh dan status gizinya (Trophina, Rompas, Yolanda, 2017).

Selain itu karena faktor lainnya yang berhubungan dengan status gizi balita, seperti status kesehatan anak balita. Sesuai dengan pendapat Soetjiningsih (2012) bahwa kesehatan anak harus mendapat perhatian dari pada orang tua yaitu dengan segera membawa anaknya yang sakit ketempat pelayanan kesehatan. Masa balita sangat rentan terhadap penyakit seperti: flu, diare, atau penyakit infeksi lainnya. Salah satu faktor yang mempermudah anak balita terserang penyakit adalah keadaan lingkungan. Faktor lainnya yang mempengaruhi adalah usia, pekerjaan serta sosial ekonomi yang dapat mempengaruhi status gizi (Trophina, Rompas, Yolanda, 2017). 
Hasil penelitian ini juga menemukan status gizi balita yang baik namun memiliki pola asuh yang tidak baik sebesar 28,1\% hal dimungkinkan karena Sikap, perilaku, dan kebiasaan orangtua selalu dilihat, dinilai, dan ditiru oleh anaknya yang kemudian semua itu secara sadar atau tidak sadar akan diresapi kemudian menjadi kebiasaan pula bagi anakanaknya. Orang tua yang mengajarkan pola makan, yang baik dan bergizi akan dicontoh oleh anaknya, orang tua yang bekerja dan memberikan hak pengasuhan kepadapengasuh/keluarga lain, dan mensuplai segala kebutuhan pangan anaknya, sebaiknya harus dikontrol, orang tua harus tetap mengawai asupan makanan yang diberikan, apabila asupan makan, baik dari bahan yang digunakan, proses pengolahan dan pola makan akan memperngaruhi status gizi anak.

Selaras dengan Soetjiningsih, (2015) pada anak-anak yang mendapat asuhan yang baik dan pemberian makanan yang cukup dan bergizi, pertumbuhan fisik maupun sel-sel otaknya akan berlangsung dengan baik. Salah satu dampak dari pengasuhan yang tidak baik adalah anak sulit makan dan obesitas atau kelebihan berat badan juga berdampak kurang baik untuk anak. Sehingga dapat terlihat bahwa pola asuh sangat berperan dalam mempengaruhi status gizi balita.

Sehingga orang tua sebaiknya menerapkan pola asuh yang baik terhadap anak, khususnya pola asuh makan yang baik. Apabila orang tua terpaksa harus bekerja, orang tua harus tetap mampu menyediaan kebutuhan pangan anak sehari-hari dengan tidak lupa dalam mengontrol setiap asupan makanan yang diberikan kepada anak.

\section{KESIMPULAN}

Proporsi karakteristik ibu yang menjadi responden adalah 76,7\% memiliki umur $\geq 25$ Tahun, 55,0\% berpendidikan D3/S1/S2, dan $56,7 \%$ bekerja. Proporsi ibu yang menjadi responden dengan pola asuh yang tidak baik adalah 53,3\%. Proporsi ibu yang menjadi responden yang memiliki balita dengan ststus gizi tidak baik adalah 43,3. Ada hubungan yang bermakna antara pola asuh ibu yang menjadi responden dengan status gizi balita $(\mathrm{p}<0.05)$

\section{DAFTAR PUSTAKA}

Lourine, Vicka Rapar.dkk 2014. Hubungan Pola asuh dengan satus gizi balita di wilayah kerja puskesmas ranotana weru kecamatan wanea kota manado. [Skripsi Program Studi Ilmu Keperawatan Fakultas Kedokteran Univerwitas Sam Ratulangi Manado].

Lubis, Ritayani. 2008. Hubungan Pola Asuh Ibu Dengan Status Gizi Anak Balira Di Wilayah Kerja Puskesmas Pantai Cermin Kecamatan Tanjung Pura Kabupaten Langkat Tahun 2008 [Skripsi fakultas kesehatan masyarakat Universitas Sumatera Utara. 2008]

Trophina, SM, Rompas.S, Yolanda, BB. Hubungan Pola Asuh dengan Status Gizi Pada Anak di Taman Kanak-Kanak Kecamatan Pulutan Kabupaten Talaud. Ejournal keperawatan (e-Kp) Volume 5 Nomor 2, Agustus 2017.

Debora. CN, Juffrie, M. Huriyati, E. Riwayat pola asuh, pola makan, asupan zat gizi berhubungan dengan stunting pada anak 24-59 bulan di Biboki utara, timor tengah utara, nusa tenggara timur. Jurnal Gizi dan Dietetik Indonesia Vol 1, No. 3, September 2013: 151-163.

Organization WH. WHO child growth standards : length/height-for-age, weight-for-age, weightfor lenght, weight-for-height and body mass index-for-age : methods and development. Geneva: Departement of Nutrition for Health and Development; 2006.

Sudargo T, Nugraheni S, Utami A, Fajrin A, Qurniati A, Puspaningtyas D, et al. Stunted is related to cognitive function of school children : a cross sectional study. Bangkok; 2010. 3.

Peng Y, Huang B, Biro F, Feng L, Guo Z, 
Slap G. Outcome of low birthweight in china :a 16-year longitudinal study. Acta Paediatr.2005;94(7):843-9.

Kar B, Rao S, Chandramouli B. Cognitive developmnet in children with chronic protein energy malnutrition. Behav Brain Funct.2008;4(31).

Utara DKTT. Laporan tahunan gizi. Timor Tengah Utara: Dinas Kesehatan Timor Tengah Utara; 2009.

Madiyono Bm, Sastroasmoro S, Budiman I, Purwanto S. Perkiraan besar sampel dasar -dasar metodologi penelitian klinis. Jakarta: Binarupa Aksara; 2002.

Amin A. Hubungan pola asuh dan asupan gizi terhadap status gizi anak usia 6-24 bulan pada daerah pesisir pantai di Kelurahan Mangempang Kecamatan Barru Kabupaten Barru. Universitas Gadjah Mada Yogyakarta; 2003

Dewi L, (2011). Hubungan Status Gizi Dengan Perkembangan Anak Usia 3-5 Tahun Di Puskesmas Purwantoro I Wonogiri. Http//jurnal.akbidmu.ac.id/index.php/jurn almus/article/download/. Diakses (24 april 2017).

Eniyati. (2011). Hubungan Antara Pola Asuh Orang Tua Dengan Status Gizi Balita. http://download.portalgaruda.org/article.p hp\%3Farticle\%3D413676\%. Diakses (27 April 2017).

Fatimah. L, (2010). Hubungan Pola Asuh Orang Tua Dengan Perkembangan Anak Di R.A Darusalam Desa Sumber Mulyo JorotoJombang.http://www.journal.unipd u.ac.id/index.php/seminas/article/downloa d/163/110 Diakses (4 mei 2017).

Hardinsyah $\mathrm{M}$ dan. Penentuan kebutuhan gizi dan kesepakatan harmonisasi di Asia Tenggara. Widya Karya Pangan dan Gizi VII. 2004. p. 301-7.

Aswatini, Romdiati H, Setiawan B, Latifa A, Fitranita, Noveria M. Ketahanan Pangan Rumah Tangga di Pedesaan : Konsep dan Ukuran. Pusat Penelitian Kependudukan [Internet]. LIPI. 2005 [cited 2010 Oct 15]. Available from: http:// www.ppk.lipi.go.id.
Badan Penelitian dan Pengembangan Kesehatan. Laporan Riskesdas tahun 2007. Jakarta: Badan Litbangkes RI; 2007.

Anwar M. Peranan gizi dan pola asuh dalam meningkatkan tumbuh kembang anak [Internet]. 2008 [cited 2011 Mar 22]. Available from: http://www. whandi.net 